\title{
The Increased Likelihood in the 21st Century for a Tropical Cyclone to Rapidly Intensify When Crossing a Warm Ocean Feature-A Simple Model's Prediction
}

Leo Oey

\section{check for} updates

Citation: Oey, L. The Increased Likelihood in the 21st Century for a Tropical Cyclone to Rapidly Intensify When Crossing a Warm Ocean

Feature-A Simple Model's

Prediction. Atmosphere 2021, 12, 1285. https: / / doi.org/10.3390/

atmos12101285

Academic Editors: Ziqian Wang, Lin Chen, Shang-Min Long and Gen Li

Received: 19 August 2021

Accepted: 30 September 2021

Published: 2 October 2021

Publisher's Note: MDPI stays neutral with regard to jurisdictional claims in published maps and institutional affiliations.

Copyright: (C) 2021 by the author. Licensee MDPI, Basel, Switzerland. This article is an open access article distributed under the terms and conditions of the Creative Commons Attribution (CC BY) license (https:// creativecommons.org/licenses/by/ $4.0 /)$.
Forrestal Campus, Princeton University, Princeton, NJ 08544, USA; lyo@alumni.princeton.edu

Abstract: A warm ocean feature (WOF) is a blob of the ocean's surface where the sea-surface temperature (SST) is anomalously warmer than its adjacent ambient SST. Examples are warm coastal seas in summer, western boundary currents, and warm eddies. Several studies have suggested that a WOF may cause a crossing tropical cyclone (TC) to undergo rapid intensification (RI). However, testing the "WOF-induced RI" hypothesis is difficult due to many other contributing factors that can cause RI. The author develops a simple analytical model with ocean feedback to estimate TC rapid intensity change across a WOF. It shows that WOF-induced RI is unlikely in the present climate when the ambient SST is $\lesssim 29.5^{\circ} \mathrm{C}$ and the WOF anomaly is $\lesssim+1{ }^{\circ} \mathrm{C}$. This conclusion agrees well with the result of a recent numerical ensemble experiment. However, the simple model also indicates that RI is very sensitive to the WOF anomaly, much more so than the ambient SST. Thus, as coastal seas and western boundary currents are warming more rapidly than the adjacent open oceans, the model suggests a potentially increased likelihood in the 21st century of WOF-induced RIs across coastal seas and western boundary currents. Particularly vulnerable are China's and Japan's coasts, where WOF-induced RI events may become more common.

Keywords: rapid intensification; typhoons; tropical cyclones; warm ocean features; coastal seas; western boundary currents; warm eddies; western North Pacific; China and Japan coasts

\section{Introduction}

A tropical cyclone (TC) is said to undergo rapid intensification (RI) when its maximum $10-\mathrm{m}$ wind increases by more than $15.4 \mathrm{~m} / \mathrm{s}$ in 1 day [1]. RI may be due to TC internal dynamics, environmental factors, and a combination [2-16]. Often, storms that have undergone RI develop into major storms (Category 3 and above) [17,18]. They are therefore of interest to researchers and forecasters.

By supplying heat and moisture to the atmosphere, ocean, and coupled ocean feedback play a significant role in TC intensity change [19-21]. Some studies suggested that RI may be triggered when a TC crosses a warm ocean feature (WOF) [12,22-29]. The WOF may be a warm eddy, a western boundary current, or a summertime coastal shelf sea. It has an anomalously warmer sea-surface temperature (SST) than the ambient sea. We define WOF-induced RI when the RI triggered as a TC crosses a WOF. In practice, however, isolating and identifying WOF-induced RI is challenging due to the simultaneous existence of other factors cited above. Oey and Huang [30] designed numerical ensemble experiments to eliminate other potential RI-causing environmental factors and isolate the WOF-induced intensity change. They conducted twin experiments and showed statistically indistinguishable RI occurrences between the experiments with and without the WOF. They then used a strip-down version of the analytical model presented here to support their numerical findings.

In this manuscript, we extend and provide complete details of the analytical model. The analytical model includes ocean feedback and estimates the WOF-induced intensity 
change and RI. The model shows that ocean feedback decreases intensity change, necessitating a warmer WOF anomaly for a TC to develop RI. We provide observations and conclude that WOF-induced RI is unlikely under the present background and WOF SSTs in the tropics and subtropics. However, WOFs can potentially play an increasingly significant role in triggering RIs as these SSTs, particularly the WOF SST, continue to rise in a warming climate.

\section{The Model}

\subsection{The Problem}

A tropical cyclone (TC) translates westward along the negative $x$-axis at a constant speed $U_{h}$. Across $x=0$, the SST $(T)$ changes by $\delta T_{W}$ due to a WOF:

$$
\begin{array}{rlr}
\mathrm{T} & =\mathrm{T}_{0} & \mathrm{x} \geq 0, \\
& =\mathrm{T}_{0}+\delta \mathrm{T}_{\mathrm{w}} & \mathrm{x}<0,
\end{array}
$$

where $\mathrm{T}_{0}$ is the ambient or background sea-surface temperature before the WOF (Figure 1). (For convenience, the variables are defined both in the text and in the Appendix A). The TC crosses onto the WOF where $\delta \mathrm{T}_{\mathrm{W}}>0$. We focus on the redpoint shortly after the crossing under the direct path of the storm's core or eyewall, where SST changes, and ocean feedback can most influence intensity $[19,31,32]$. The goal is to calculate the change in the maximum wind $\left(\delta \mathrm{V}_{\mathrm{m}}\right)$ and estimate the $\left(\delta \mathrm{T}_{\mathrm{W}}, \mathrm{T}_{0}\right)$-combination where a WOF-induced RI is possible. The analysis is independent of where the redpoint is, provided it is in the WOF and the direct path of the storm's core.

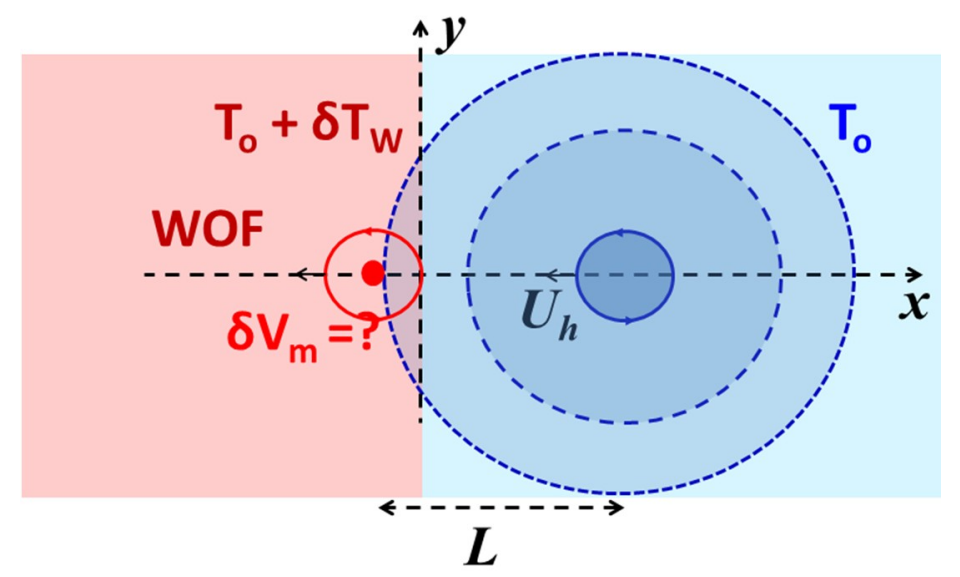

Figure 1. A tropical cyclone (TC) translates westward at a constant $\mathrm{U}_{\mathrm{h}}$ across $\mathrm{x}=0$ onto a warm ocean feature (WOF) where SST increases by $\delta \mathrm{T}_{\mathrm{W}}$. The circles depict the TC wind from weak, e.g., $18 \mathrm{~m} / \mathrm{s}$ in the outer circle of radius $\mathrm{L}$ to the maximum in the inner-most 'core'. As the storm approaches, wind at the redpoint strengthens from weak to the maximum over a time $\sim \mathrm{L} / \mathrm{U}_{\mathrm{h}}$ shortly after the storm crosses into the WOF. The goal is to calculate the increased wind $\delta \mathrm{V}_{\mathrm{m}}$ due to the coupled response of the WOF and ocean cooling.

\subsection{Intensity Change Due to the WOF: The WOF-Induced RI}

The TC experiences a warmer SST as it crosses $x=0$. The warmer SST increases the wind, which we can estimate using the maximum potential intensity (MPI) theory [19]. We use the empirical form given by DeMaria and Kaplan [33]:

$$
\mathrm{V}_{\mathrm{m}}=\mathrm{A}+\mathrm{B} e^{\mathrm{C}(\mathrm{T}-30)} .
$$

Here, $\mathrm{V}_{\mathrm{m}}(\mathrm{m} / \mathrm{s})$ is the maximum wind, the SST T is in ${ }^{\circ} \mathrm{C}$, and A, B, and C are empirical coefficients. DeMaria and Kaplan [33] limit the applicability of Equation (2) to $\mathrm{T} \leq 30^{\circ} \mathrm{C}$. However, later extensions using higher-resolution data suggest no such limit $[6,34,35]$. The 
change in the maximum wind, $\delta \mathrm{V}_{\mathrm{m}}$, due to a change in SST, $\delta \mathrm{T}$, i.e., the WOF-induced intensity change, is:

$$
\delta \mathrm{V}_{\mathrm{m}}=\mathrm{s} \delta \mathrm{T}+\mathrm{sC} \delta \mathrm{T}^{2} / 2+0\left(\delta \mathrm{T}^{3}\right) ; \mathrm{s}(\mathrm{T})=\left.\left(\partial \mathrm{V}_{\mathrm{m}} / \partial \mathrm{T}\right)\right|_{0},
$$

where (..) $\left.\right|_{0}$ means evaluation at the ambient state $\mathrm{T}_{0}$, and $\mathrm{s}$ is the slope of $\mathrm{V}_{\mathrm{m}}$ in the T-space. Partial derivatives are a reminder that $(\mathrm{A}, \mathrm{B}, \mathrm{C})$ may not depend on $\mathrm{T}$ alone. We assume the increased intensity occurs within one day of the storm crossing $\mathrm{x}=0$ and define WOFinduced RI when $\delta V_{m} \geq 15.4 \mathrm{~m} / \mathrm{s}$. The vast majority (85\%) of RI events occur in storms that translate faster than $\sim 3 \mathrm{~m} / \mathrm{s}$ [36]. The assumption is reasonable since the time for the TC core to cross a WOF of typical size 100-200 km [30] is one day or less. By definition, $\mathrm{V}_{0} \lesssim \mathrm{V}_{\mathrm{m}}$, where $\mathrm{V}_{0}$ is the maximum wind of the TC approaching the WOF. We will see that $\delta \mathrm{V}_{0} \lesssim \delta \mathrm{V}_{\mathrm{m}}$ (see Section 2.3.6 below). Therefore, the above RI criterion " $\delta \mathrm{V}_{\mathrm{m}} \geq 15.4 \mathrm{~m} / \mathrm{s}$ " is more easily satisfied than the conventional RI criterion " $\delta \mathrm{V}_{0} \geq 15.4 \mathrm{~m} / \mathrm{s}$ ". In other words, if the model predicts RI to be unlikely in the present climate, as will be shown to be the case, using the conventional criterion leads to the same conclusion.

\subsection{Ocean Feedback}

The increased $\delta \mathrm{V}_{\mathrm{m}}$ in the WOF (the red point) increases ocean mixing and upwelling $[37,38]$, hence SST cooling, $\delta \mathrm{T}_{0}<0$, which reduces $\delta \mathrm{V}_{\mathrm{m}}$. The reduced $\delta \mathrm{V}_{\mathrm{m}}$ modifies the amount of cooling, which further changes the $\delta \mathrm{V}_{\mathrm{m}}$, in a coupled manner.

\subsubsection{Assumptions}

We assume an ocean with no horizontal variation. For example, the SST front at $x=0$ is fixed and has no dynamics. Vertical mixing then predominantly controls the SST cooling under super-critically translating storms when $U_{h} / c>1$, where $c$ is the ocean's mode-1 baroclinic phase speed [39]. In the tropical and subtropical oceans, $\mathrm{c} \approx 2.5 \sim 3 \mathrm{~m} / \mathrm{s}$ [40,41]. Thus, we require that $\mathrm{U}_{\mathrm{h}}$ exceeds $\sim 3 \mathrm{~m} / \mathrm{s}$. Then we may neglect the contribution to SST cooling from horizontal processes, such as upwelling and mixing due to breaking nearinertial internal waves [42]. For $U_{h} \geq 3 \mathrm{~m} / \mathrm{s}$ and a typical TC core's diameter of 100-200 km (e.g., ref. [43]), a point in the storm's path remains influenced by the maximum wind stress curl for at most 8-18 hours. This time is less than the inertial time $>1$ day (for latitudes $<28^{\circ}$ ) required for wind curl-driven upwelling to establish and contribute significantly to SST cooling $[39,44]$. It is also less than the time required for near-inertial internal waves to develop and contribute to mixing [45,46]. As mentioned before, global TC observations also show that most $R I$ events occur in storms with $U_{h}>3 \mathrm{~m} / \mathrm{s}[6,36]$, providing a further incentive to focus on these storms. The one-dimensional model underestimates cooling for slow storms with $\mathrm{U}_{\mathrm{h}} \lesssim 3 \mathrm{~m} / \mathrm{s}$. Additional SST cooling due to horizontal processes mentioned above can be more significant for slow storms. However, as will become apparent, any additional cooling can only weaken the TC intensity and not change our conclusions. The one-dimensional model then provides an upper-bound intensity change.

\subsubsection{Two-Layer Ocean}

We divide the ocean into two active layers of thicknesses, $h_{1}$ and $h_{2}$. Layer 1 consists of warm water of a uniform temperature $\mathrm{T}_{1}$ and density $\varrho_{1}$ from sea-surface $\mathrm{z}=0$ to $\mathrm{z}=-\mathrm{h}_{1}$. Layer 2 consists of cooler water of uniform temperature $T_{2}\left(<T_{1}\right)$ and density $\varrho_{2}\left(>\varrho_{1}\right)$ from $\mathrm{z}=-\mathrm{h}_{1}$ to $\mathrm{z}=-\left(\mathrm{h}_{1}+\mathrm{h}_{2}\right)$ (a third layer below extending to the ocean bottom is assumed to be inactive). Suppose the wind adiabatically mixes the two layers into a single layer, the uniform density and temperature after mixing (subscript 'mix') are weighted averages of layers 1 and 2:

$$
\varrho_{\text {mix }}=\left(\varrho_{2} \mathrm{~h}_{2}+\varrho_{1} \mathrm{~h}_{1}\right) /\left(\mathrm{h}_{1}+\mathrm{h}_{2}\right), \quad \mathrm{T}_{\text {mix }}=\left(\mathrm{T}_{2} \mathrm{~h}_{2}+\mathrm{T}_{1} \mathrm{~h}_{1}\right) /\left(\mathrm{h}_{1}+\mathrm{h}_{2}\right),
$$


expressing mass and heat conservations. The SST after mixing is:

$$
\mathrm{T}_{\text {mix }}=\mathrm{T}_{1}+\delta \mathrm{T}, \quad \delta \mathrm{T}=-\left[\mathrm{h}_{2} /\left(\mathrm{h}_{1}+\mathrm{h}_{2}\right)\right] \Delta \mathrm{T},
$$

where $\Delta \mathrm{T}=\mathrm{T}_{1}-\mathrm{T}_{2}(>0)$ is the differenced temperature of the two original layers. The corresponding differenced density $\Delta \varrho=\varrho_{1}-\varrho_{2}(<0)$ :

$$
\Delta \varrho / \varrho_{0}=-\alpha \Delta \mathrm{T},
$$

where $\varrho_{0}$ is the reference seawater density $\approx 1025 \mathrm{~kg} / \mathrm{m}^{3}$, and $\alpha=(\partial \varrho / \partial \mathrm{T}) / \varrho_{0}$ is the thermal expansion coefficient of seawater, $\approx 3 \times 10^{-4} \mathrm{~K}^{-1}$ at the sea surface with SST $\approx 28^{\circ} \mathrm{C}$ and salinity $\approx 35$ psu.

\subsubsection{Potential Energy}

Wind work raises the potential energy (PE) of the fluid by mixing it. Equating the raised $\mathrm{PE}=\mathrm{PE} \mathrm{I}_{\text {mix }}-\mathrm{PE} \mathrm{I}_{\text {2layers }}$ to wind work yields a formula relating the wind to density (and temperature). Thus, since

$$
\mathrm{PE}_{2 \text { layers }}=\int_{-\mathrm{h}_{1}}^{0} \varrho_{1} \mathrm{~g} \mathrm{zdz}^{\prime}+\int_{-\mathrm{h}_{1}-\mathrm{h}_{2}}^{-\mathrm{h}_{1}} \varrho_{2} \mathrm{gzdz},
$$

and

$$
\mathrm{PE}_{\text {mix }}=\int_{-\mathrm{h}_{1}-\mathrm{h}_{2}}^{0} \varrho_{\text {mix }} \mathrm{g} \mathrm{zdz^{ \prime }}
$$

we obtain

$$
\mathrm{PE}=-(\mathrm{g} / 2) \Delta \varrho \mathrm{h}_{2} \mathrm{~h}_{1}=(\mathrm{g} / 2) \alpha \varrho_{0} \Delta \mathrm{T} \mathrm{h}_{2} \mathrm{~h}_{1} \quad\left(\mathrm{~J} / \mathrm{m}^{2}\right) .
$$

\subsubsection{Wind Energy}

The wind power on the ocean is $\varrho_{\mathrm{a}} \mathrm{C}_{\mathrm{d}} \mathrm{V}^{3}$ in $\mathrm{J} /\left(\mathrm{m}^{2} \cdot \mathrm{s}\right)$, the scalar product of the surface drag $\varrho_{\mathrm{a}} \mathrm{C}_{\mathrm{d}}|\mathbf{V}| \mathbf{V}$ and wind $\mathbf{V}$, neglecting the ocean current. Here, $\varrho_{\mathrm{a}}$ is the air density, $\mathrm{C}_{\mathrm{d}}$ is the drag coefficient, and $V=|\mathbf{V}|$ the wind speed. Due to the TC's size, the redpoint (Figure 1) experiences the wind and SST cooling hours or days before the storm arrives, depending on $\mathrm{U}_{\mathrm{h}}$. Oey et al. [37] observed this ahead-of-storm SST cooling in buoy measurements in the Caribbean Sea before the arrival of Hurricane Wilma (2005). Therefore the wind energy for mixing at the redpoint is:

$$
\mathrm{WE}=\gamma \int_{0}^{\mathrm{P}} \varrho_{\mathrm{a}} \mathrm{C}_{\mathrm{d}} \mathrm{V}^{3} \mathrm{dt}\left(\mathrm{J} / \mathrm{m}^{2}\right)
$$

Here, the mixing efficiency $\gamma$ takes into account that only a fraction of the wind work goes into mixing, and $\mathrm{P}=\mathrm{L} / \mathrm{U}_{\mathrm{h}}$, where $\mathrm{L} \approx$ storm's radius. The integral is from $\mathrm{t}=0$ when the outer-most circle of weak TC wind influences the redpoint to $t=P$ when the TC center arrives (one could formally transform the integral by setting $x=-U_{h} t+L+x_{\text {redpoint }}$ but thinking in " $\mathrm{t}$ " is more straightforward). We neglect the contribution from the generally even weaker, non-TC wind before the TC's outer-most circle arrives. We also assume that after time $t=P$, SST cooling at the redpoint will not affect intensity. For $t>P$, the TC center has passed the redpoint. Thus, ignoring the short distance across the back half of the eye, ocean cooling in the TC's wake has a minor further impact on intensity.

\subsubsection{Wind-Induced SST Cooling}

Set $\mathrm{PE}=\mathrm{WE}$, and use (5) to yield:

$$
\mathrm{T}_{\text {mix }}=\mathrm{T}_{1}-\left\{\left[\gamma \int_{0}^{\mathrm{P}} \varrho_{\mathrm{a}} \mathrm{C}_{\mathrm{d}} \mathrm{V}^{3} \mathrm{dt}\right] /\left[\left(\frac{\mathrm{g}}{2}\right) \alpha \varrho_{0} \mathrm{~h}_{2} \mathrm{~h}_{1}\right]\right\}\left[\frac{\mathrm{h}_{2}}{\mathrm{~h}_{2}+\mathrm{h}_{1}}\right] .
$$


Piecewise continuous formulae of $\mathrm{V}$ are available [43] to evaluate the integral. To obtain simple formulae, we choose to model $\mathrm{V}$ as a simple rise and fall as the TC passes the point:

$$
\mathrm{V}=\mathrm{V}_{0} \sin [\pi \mathrm{t} /(2 \mathrm{P})], \quad \mathrm{V}_{0}=\text { maximum wind, }
$$

Thus, ignoring the rapid wind change with two maxima as the TC center passes. Because of integration, the exact form is not crucial. Using Equation (12) in Equation (11), we obtain:

$$
\mathrm{T}_{\text {mix }}=\mathrm{T}_{1}-\left[\left(\frac{4}{3 \pi}\right)\left(\frac{\mathrm{L}}{\mathrm{U}_{\mathrm{h}}}\right)\left(\frac{\varrho_{\mathrm{a}}}{\varrho_{0}}\right)\left(\gamma \mathrm{C}_{\mathrm{d}} \mathrm{V}_{0}^{3}\right)\right] /\left[\left(\frac{\mathrm{g}}{2}\right) \alpha \mathrm{h} \mathrm{h}_{1}\right],
$$

where $h=h_{1}+h_{2}$. Equation (13) gives the cooled SST the arriving TC sees at a point ahead of the TC path, including the redpoint. The SST cooling $\left(=\mathrm{T}_{\text {mix }}-\mathrm{T}_{1}\right)$ is inversely related to $\mathrm{U}_{\mathrm{h}}$ and $\mathrm{h}_{1}$. It shows that a slower storm sees a cooler SST than a faster one, and a thicker upper warm layer is less susceptible to cooling than a thinner one.

\subsubsection{Coupling}

Focusing on the redpoint, as the TC crosses into the WOF, we assume that its maximum wind $V_{0}$ changes while its temporal functional form remains unchanged:

$$
\delta \mathrm{V} \approx \delta \mathrm{V}_{0} \sin [\pi \mathrm{t} /(2 \mathrm{P})] .
$$

This is a good approximation since the redpoint is only a short distance into the WOF. We can then use Equation (11) to relate the change in SST due to a change in the wind. Taking $\delta$ of Equation (11) and evaluating the integral (or taking $\delta$ of Equation (13)):

$$
\begin{gathered}
\delta \mathrm{T}_{0}=-\delta \mathrm{V}_{0} \mathrm{~F}_{\mathrm{T}} \\
\mathrm{F}_{\mathrm{T}}=\left[\left(\frac{8}{\pi}\right)\left(\frac{\mathrm{L}}{\mathrm{U}_{\mathrm{h}}}\right)\left(\frac{\varrho_{\mathrm{a}}}{\varrho_{0}}\right)\left(\mathrm{C}_{\mathrm{d}} \mathrm{V}_{0}^{2}\right)\right] /[\mathrm{g} \alpha \mathrm{h} \mathrm{h}] .
\end{gathered}
$$

The special notation $\delta \mathrm{T}_{0}$ (with subscript ' $\mathrm{o}$ ') is used instead of $\delta \mathrm{T}_{\text {mix }}$, as a reminder that it is the ocean cooling caused by increased $\delta \mathrm{V}_{0}$ as the TC crosses into the WOF. At the redpoint, the total SST change is the sum of the warmer SST due to the WOF and cooling due to ocean mixing:

$$
\delta \mathrm{T}_{\text {redpoint }}=\delta \mathrm{T}_{\mathrm{W}}+\delta \mathrm{T}_{0} .
$$

The $\mathrm{V}_{0}$ refers to the incoming TC that translates into the WOF. To close the model (i.e., to couple), one needs to relate $\delta \mathrm{V}_{0}$ to $\delta \mathrm{V}_{\mathrm{m}}$, where $\delta \mathrm{V}_{\mathrm{m}}$ depends on SST from Equation (3). A reasonable assumption is that $\delta \mathrm{V}_{0} / \delta \mathrm{V}_{\mathrm{m}}$ is proportional to $\mathrm{V}_{0} / \mathrm{V}_{\mathrm{m}}$, and we set the proportionality to one for simplicity. The assumption is equivalent to letting $\mathrm{V}_{0}$ be proportional to $\mathrm{V}_{\mathrm{m}}$, such that their ratio is approximately invariant, as the data and analysis of $[6,33-35]$ suggest. Thus:

$$
\delta \mathrm{V}_{0}=\mu \delta \mathrm{V}_{\mathrm{m}}, \mu=\mathrm{V}_{0} / \mathrm{V}_{\mathrm{m}} \leq 1 .
$$

The $\mu$ is $\lesssim 0.5$ for $\mathrm{V}_{0} \lesssim 50 \mathrm{~m} / \mathrm{s}$ and tropical/subtropical SST $\gtrsim 28^{\circ} \mathrm{C}$ (Figure 2) (in Oey and Huang [30], we set $\delta \mathrm{V}_{0}=\delta \mathrm{V}_{\mathrm{m}}$, i.e., $\mu=1$, which overestimates the cooling, although their conclusions remain unchanged).

Setting $\delta \mathrm{T}=\delta \mathrm{T}_{\text {redpoint }}$ and using Equations (15)-(18) in Equation (3) yields a quadratic equation for $\delta \mathrm{V}_{\mathrm{m}}$. Both roots are positive, but the smaller root is physically plausible:

$$
\begin{gathered}
\delta \mathrm{V}_{\mathrm{m}}=\left[\mu_{2}-\sqrt{\mu_{2}^{2}-4 \mu_{1} \mu_{3}}\right] /\left[2 \mu_{1}\right] \\
\mu_{1}=\mathrm{sC}\left(\mu \mathrm{F}_{\mathrm{T}}\right)^{2} / 2, \mu_{2}=1+\left(1+\mathrm{C} \delta \mathrm{T}_{\mathrm{W}}\right){\mathrm{s} \mu \mathrm{F}_{\mathrm{T}},}, \\
\mu_{3}=\mathrm{s} \delta \mathrm{T}_{\mathrm{W}}\left(1+\mathrm{C} \delta \mathrm{T}_{\mathrm{W}} / 2\right) .
\end{gathered}
$$

Taylor's expansion in small $\mathrm{F}_{\mathrm{T}}$ shows that the solution tends to Equation (3) without ocean cooling as $\mathrm{F}_{\mathrm{T}} \sim 0$. 


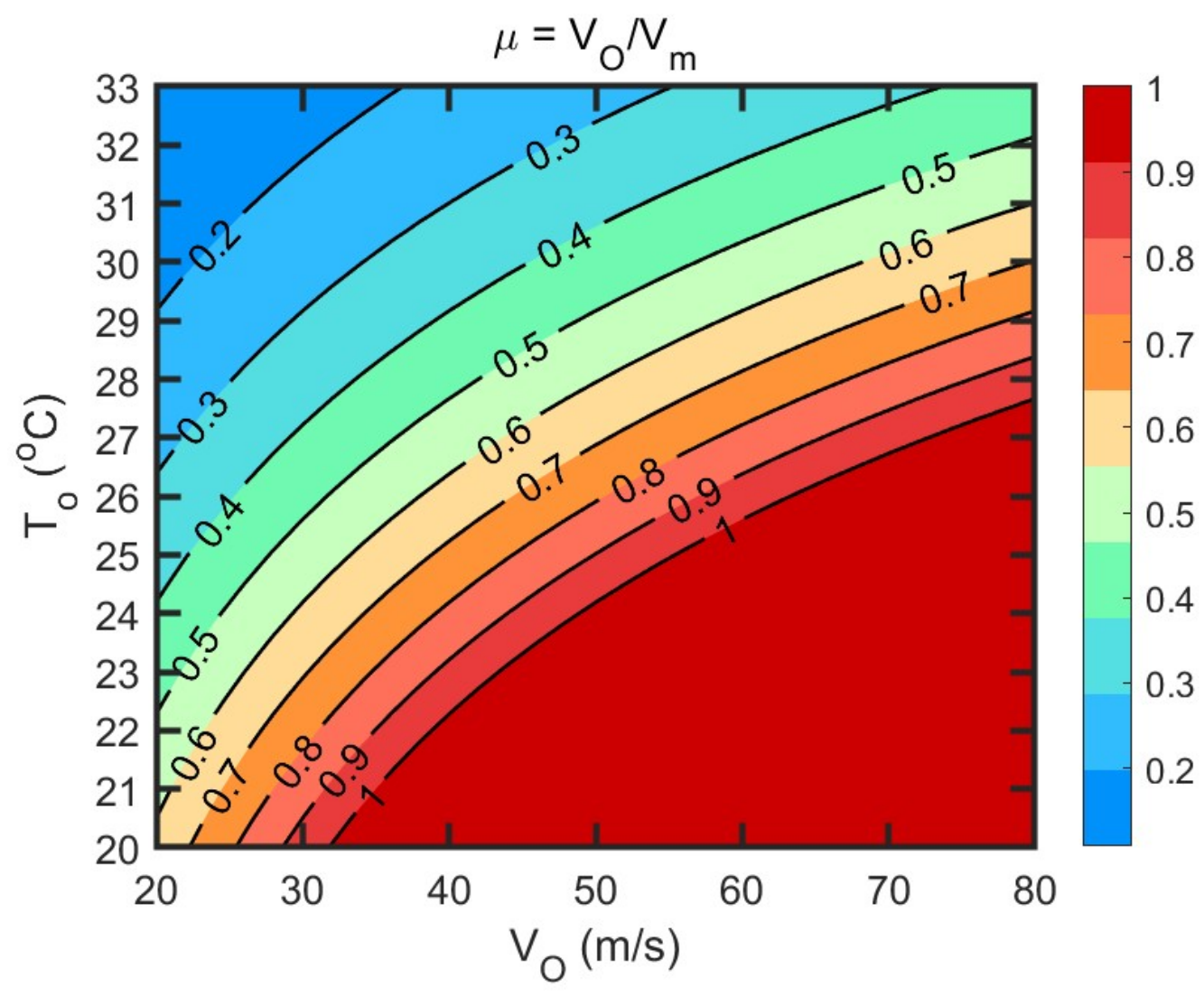

Figure 2. Plot of $\mu=V_{0} / V_{m}$.

Although Equation (19) will be used in the plots, we can more easily see the effect of ocean feedback by dropping the $\mathrm{O}\left(\delta \mathrm{T}^{2}\right)$ term in Equation (3). The solution is:

$$
\delta \mathrm{V}_{\mathrm{m}}=\mathrm{s}\left(\mathrm{T}_{0}\right) \delta \mathrm{T}_{\mathrm{W}} /\left[1+\mathrm{s}\left(\mathrm{T}_{0}\right) \mu \mathrm{F}_{\mathrm{T}}\right],
$$

where $s\left(T_{0}\right)$ is a reminder that it depends on the ambient SST $T_{0}$.

\subsubsection{Values of Parameters}

We use the following values of the model parameters:

$\mathrm{A}=15.69(2758) \mathrm{m} / \mathrm{s}, \mathrm{B}=98.03(74.03) \mathrm{m} / \mathrm{s}$, and $\mathrm{C}=0.1806(0.1903){ }^{\circ} \mathrm{C}^{-1}$ for western North Pacific (North Atlantic), from Zeng et al. [6] (Xu et al. [35]), see Equation (2);

$\mathrm{L}=200 \mathrm{~km}$, the TC's radial scale (roughly to $\sim 18 \mathrm{~m} / \mathrm{s}$ ) [40];

$\varrho_{\mathrm{a}} / \varrho_{0}=10^{-3}$, the ratio of air to seawater densities;

$\gamma=0.02$, see below;

$\mathrm{C}_{\mathrm{d}}=2 \times 10^{-3}$, the drag coefficient at high wind speeds [47];

$\mathrm{g}=10 \mathrm{~m} / \mathrm{s}^{2}$, the Earth's gravity;

$\alpha=3 \times 10^{-4} \mathrm{~K}^{-1}$, seawater's thermal expansion coefficient [39];

$\mathrm{h}_{1}$ and $\mathrm{h}_{2}$ are chosen to be from the surface to the $26^{\circ} \mathrm{C}$ isotherm $\mathrm{z}=-\mathrm{z}_{26}$, and from $\mathrm{z}=-\mathrm{z}_{26}$ to the $20{ }^{\circ} \mathrm{C}$ isotherm $\mathrm{z}=-\mathrm{z}_{20}$. The $\mathrm{h}_{1} \approx \mathrm{h}_{2} \approx 100 \mathrm{~m}$ in the RI region $\left(10 \sim 25^{\circ} \mathrm{N}\right)$ in the tropical and subtropical western North Pacific (Figure 3). 

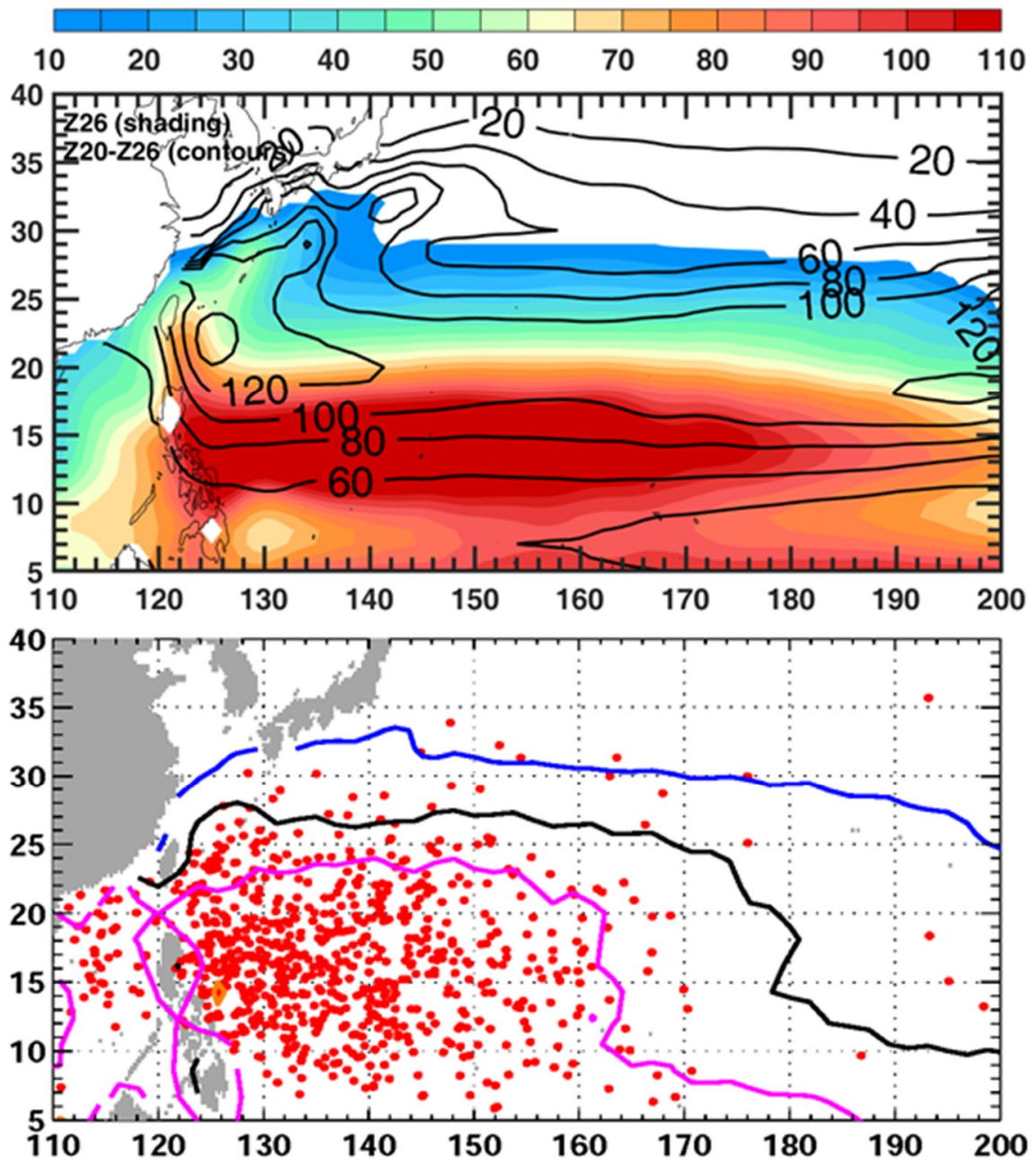

Figure 3. Top: mean Z26 $\left(=\mathrm{h}_{1}\right)$ and $\mathrm{Z} 20-\mathrm{Z} 26\left(=\mathrm{h}_{2}\right.$, contours) $(\mathrm{m})$ from the EN4 reanalysis [46]. Bottom: RI locations as red dots [15] from IBTrACS (https://www.ncdc.noaa.gov/ibtracs/ accessed on 1 October 2021) and SST contours $26,28,29$, and $30^{\circ} \mathrm{C}$ (blue, black, magenta, and orange). Only a few $30^{\circ} \mathrm{C}$ contours exist close to the Philippines' eastern coast. The period is 1992-2015 June-September.

\section{Choosing $\gamma$ :}

Given $Z_{26}$ and $Z_{20}$ as a slowly-varying background ocean state, one can calculate the SST cooling $\delta \mathrm{T}\left(\mathrm{Z}_{26}, \mathrm{Z}_{20}, \mathrm{U}_{\mathrm{h}}, \mathrm{V}_{0} ; \gamma\right)$ (Equation (13)) along a storm's track with $\gamma$ serving as a parameter. Here we use the EN4 data as the ocean state given as monthly analysis from 1900 to the present [48]. We calculate $\mathrm{U}_{\mathrm{h}}$ and $\mathrm{V}_{0}$ at a track location using the average of the present and previous day's values. We then choose $\gamma$ to yield SST cooling that reasonably matches the observed and full ocean model's cooling in two TCs: Typhoon Nuri (2008) and Typhoon Soudelor (2015). We previously conducted detailed analyses and SST cooling simulations for these typhoons using the Princeton ocean model (POM) $[16,49,50]$. We find that $\gamma=0.02$ gives reasonably good agreements between $\delta \mathrm{T}$ and SST cooling from GHRSST observation and POM (Figure 4). The $\gamma=0.02$ is within the range cited in the literature for strong boundary stirring at high buoyancy Reynolds number [51-54]. 


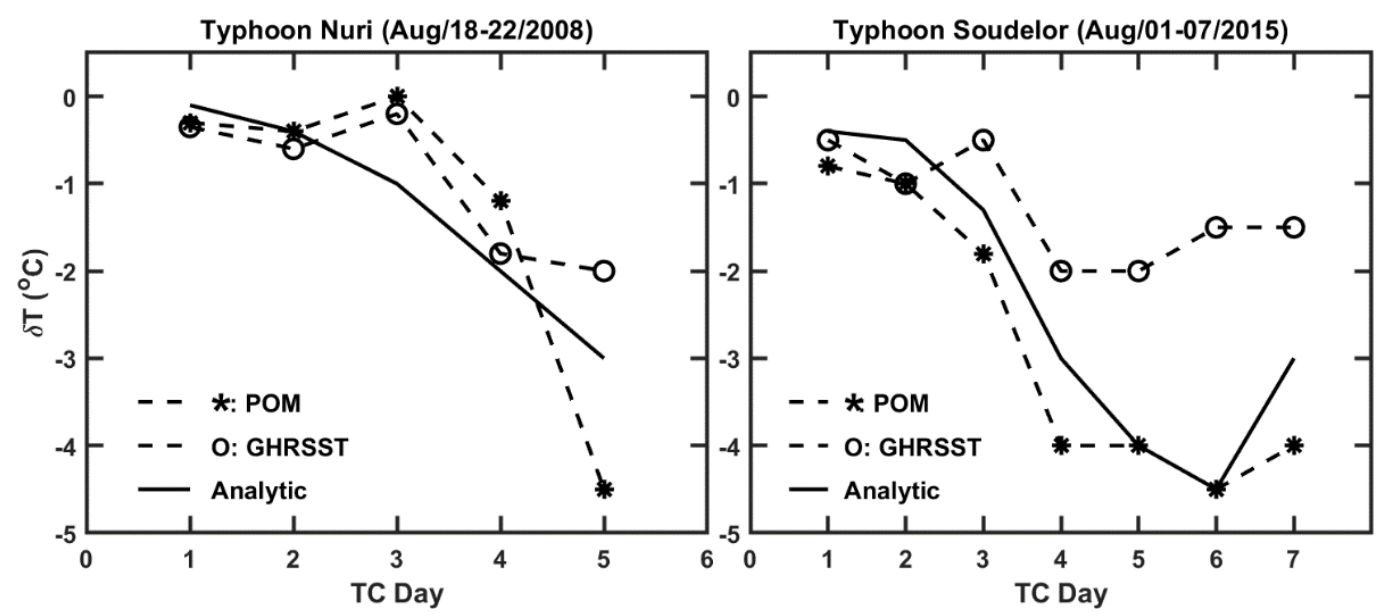

Figure 4. Comparisons of the analytical SST cooling (with $\gamma=0.02$ ) with GHRSST (Group for High resolution Sea Surface Temperature, https:/ / www.ghrsst.org/ accessed on 1 October 2021) and three-dimensional POM simulated cooling along the daily track of Typhoons Nuri [49,50] and Soudelor [16]. Note that due to interpolation GHRSST tends to underestimate TC-induced SST cooling [49]. For Nuri, the discrepancy on Day 3 is due to the storm crossing the warm Kuroshio in the Luzon Strait, which the simple model poorly represents.

\section{Results}

We describe the modeled WOF-induced intensity change $\delta \mathrm{V}_{\mathrm{m}}$, focusing first on the western North Pacific's typhoons since these have the largest intensity changes. Then, however, we will comment on the North Atlantic's hurricanes.

\section{1. $\delta V_{m}$ with No Ocean Feedback}

Figure 5 (color shading) shows $\delta \mathrm{V}_{\mathrm{m}}$ without ocean feedback as a function of $\delta \mathrm{T}_{\mathrm{W}}$ and $\mathrm{T}_{0}$. Mathematically, it is equivalent to the maximum possible increased intensity as the storm enters the WOF at an infinite translation speed $U_{h}$. There is then little time for ocean mixing by the wind to cool the sea surface. It is also the $\delta V_{m}$ when the TC crosses onto a shallow warm sea where the entire water column is well-mixed. The white line shows the corresponding $\delta \mathrm{V}_{\mathrm{m}}=15.4 \mathrm{~m} / \mathrm{s}$ separating the $\left(\delta \mathrm{T}_{\mathrm{W}}, \mathrm{T}_{0}\right)$ on the upper right where a WOF-induced RI is possible from the lower-left where RI is unlikely. Figure 5 uses $\mathrm{V}_{0}=30 \mathrm{~m} / \mathrm{s}$ as a representative example. Most observed RIs develop when the TC is in the tropical storm (TS) or Categories $1-2$ stages $[15,17,18,30,36]$. However, the $\delta V_{m}=15.4 \mathrm{~m} / \mathrm{s}$ line in this plot and Figure 6 , hence the inferences derived from it are independent of $V_{0}$ since the line is for the asymptotic limit of zero ocean cooling. The present climatological SST $\left(\mathrm{T}_{0}\right)$ in the RI region is $28-29.5^{\circ} \mathrm{C}$ (Figure 3 ). The composite (1993-2015) mean eddy's SST anomaly is $+0.3^{\circ} \mathrm{C}[55]$, but $\delta \mathrm{T}_{\mathrm{W}}$ in individual WOFs can reach $+1^{\circ} \mathrm{C}[15,16,24,27]$. For reference, white dashed lines indicate the present climate's $\left(\delta \mathrm{T}_{\mathrm{W}}, \mathrm{T}_{0}\right)=(1,29){ }^{\circ} \mathrm{C}$. As the majority $(\sim 85 \%)$ of RIs occur for $U_{h} \lesssim 7 \mathrm{~m} / \mathrm{s}[6,36]$, the result suggests that RIs triggered by the WOF alone are unlikely to be frequent occurrences in the present climate. In other words, factors other than WOF alone more likely trigger the RIs observed in the present climate. See Section 3.3. 


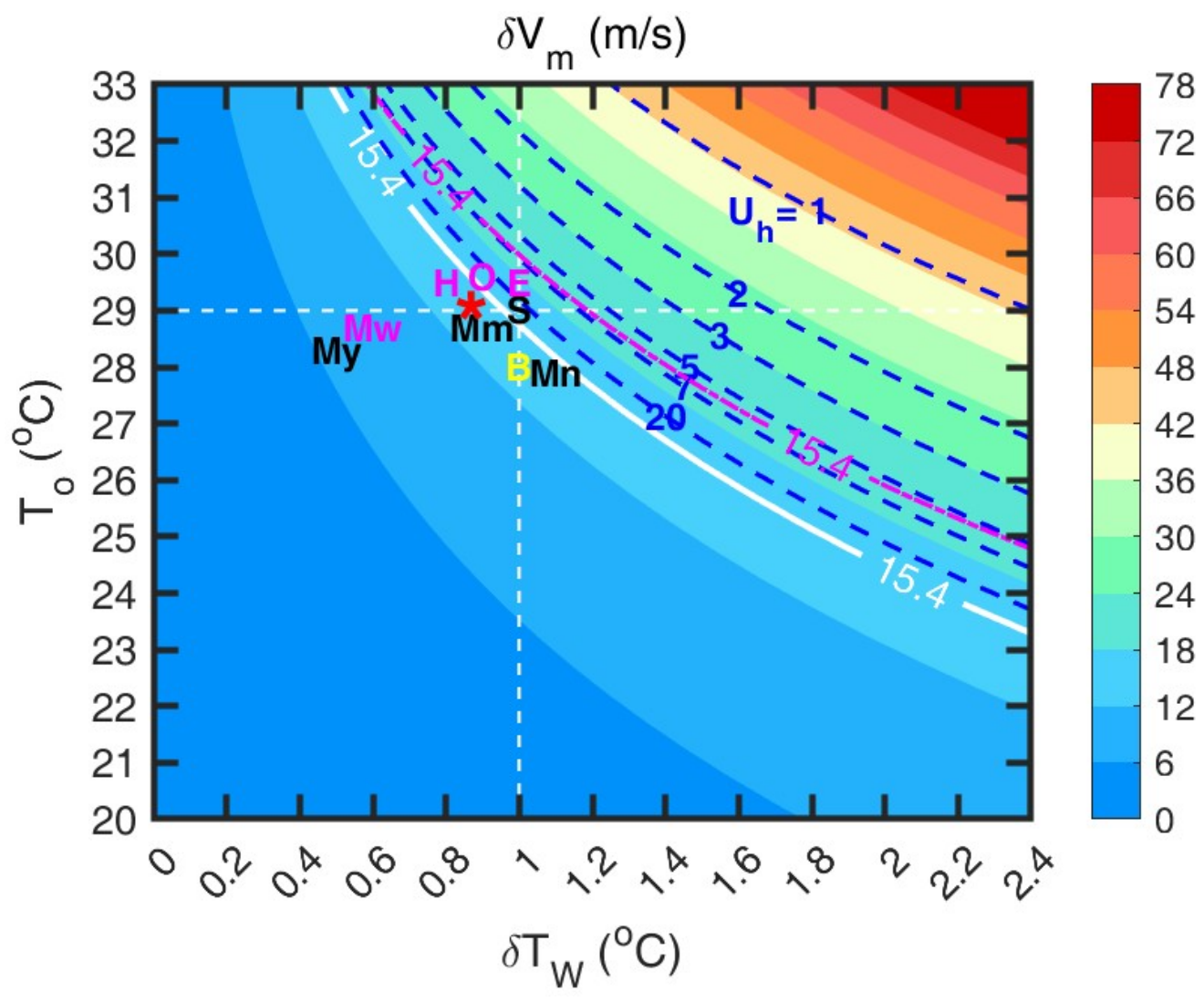

Figure 5. Color shading: western North Pacific's $\delta V_{m}$ for $U_{h}=\infty$ (i.e., no ocean feedback) as TC encounters a WOF with $\delta \mathrm{T}_{\mathrm{W}}$ warmer than the ambient $\mathrm{T}_{0}$; white line is $\delta \mathrm{V}_{\mathrm{m}}=15.4 \mathrm{~m} / \mathrm{s}$. Blue dashed lines are $15.4 \mathrm{~m} / \mathrm{s}$ with ocean feedback for various $U_{h}$. White dashed lines mark $T_{0}=29^{\circ} \mathrm{C}$ and $\delta \mathrm{T}_{\mathrm{W}}=1{ }^{\circ} \mathrm{C}$. Letters are observed RI TCs: Bansi (2015; pre-RI intensity (pRIi) Cat.2) [28], Earl (2010; pRIi Cat.1) [27], Harvey (2017; pRIi TS) [29], Maemi (2003; pRIi Cat.1) and Maon (2004; pRIi Cat.1) [24], Manyi (2013; pRIi TS) [12], Matthew (2016; pRIi Cat.1) [56], Opal (1995; pRIi Cat.1) [22], and Soudelor (2015; pRIi TS) [16]. The red asterisk is their mean. The $U_{h}$ ranges from $3(\mathrm{Mn})$ to $8.5 \mathrm{~m} / \mathrm{s}(\mathrm{O})$. The magenta line is $\delta \mathrm{V}_{\mathrm{m}}=15.4 \mathrm{~m} / \mathrm{s}$ for the $\mathrm{N}$ Atlantic (no ocean feedback). The model uses $\gamma=0.02, \mathrm{~h}_{1}=\mathrm{h}_{2}=100 \mathrm{~m}$ and $\mathrm{V}_{0}=30 \mathrm{~m} / \mathrm{s}$.

\section{2. $\delta V_{m}$ with Ocean Feedback}

In Equation (20), the " $\mathrm{s} \times \delta \mathrm{T}_{\mathrm{W}}$ " is the MPI estimate of the WOF-induced intensification. The " $\mathrm{s} \times \mu \mathrm{F}_{\mathrm{T}}$ " $(>0)$ is the coupling term that includes the contribution $\left(\mathrm{F}_{\mathrm{T}}\right)$ from ocean cooling caused by the mixing of surface and subsurface water by the translating storm. The formula shows that ocean cooling always reduces $\delta \mathrm{V}_{\mathrm{m}}$. Since $\mathrm{F}_{\mathrm{T}}$ is inversely related to $\mathrm{U}_{\mathrm{h}}$ and $\mathrm{h}_{1}$ (see Equation (16)), the ocean cools more for slower storms, a thinner upper warm layer, or both, which then reduces $\delta \mathrm{V}_{\mathrm{m}}$. For very deep $\mathrm{h}_{1}, \mathrm{~F}_{\mathrm{T}} \sim 0$, and ocean feedback is negligible. Ocean feedback is also weak for very fast storms since there is little time for the wind to mix the upper ocean, and the feedback to the storm is negligible. In either case, the intensification is due to the WOF alone and becomes the upper-bound MPI estimate: $\delta \mathrm{V}_{\mathrm{m}}=\mathrm{s} \times \delta \mathrm{T}_{\mathrm{W}}$.

The blue dashed lines in Figure 5 show the $\delta \mathrm{Vm}=15.4 \mathrm{~m} / \mathrm{s}$ contours obtained from the solution with ocean feedback for different $U_{h}$. (The plot is for the solution 19, although the quadratic correction is small: $5-10 \%$ less cooling). Ocean cooling at finite $U_{h}$ shifts the $15.4 \mathrm{~m} / \mathrm{s}$ line rightward and upward, meaning ocean feedback makes it even harder for WOF-induced RI to develop under the present climate. 


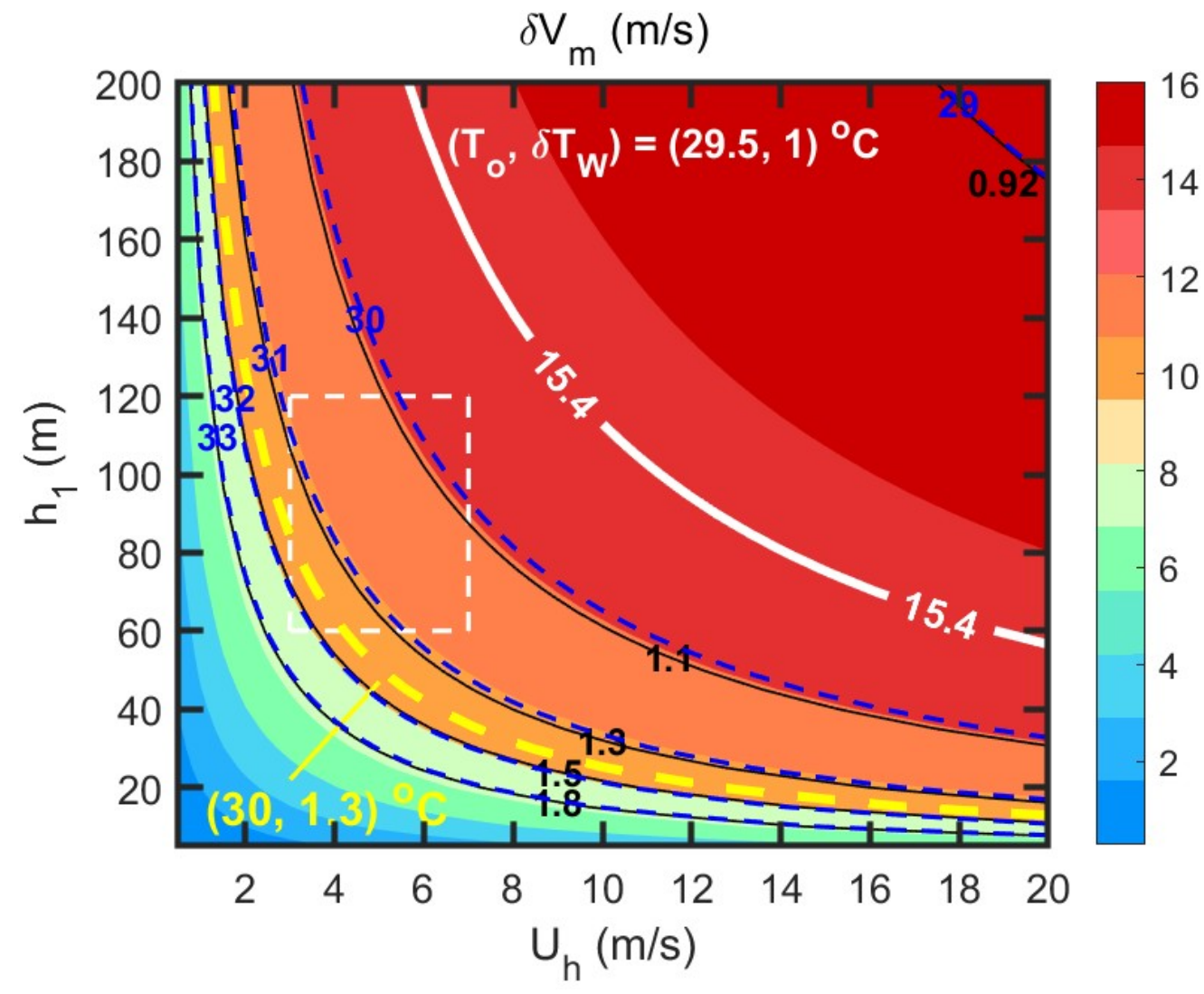

Figure 6. Western North Pacific's $\delta V_{m}$ as a function of $U_{h}$ and $h_{1}$ for $\left(T_{0}, \delta T_{W}\right)=(29.5,1){ }^{\circ} \mathrm{C}$ (shading and white $15.4 \mathrm{~m} / \mathrm{s}$-line). Other lines are $15.4 \mathrm{~m} / \mathrm{s}$ for blue dashed: $\mathrm{T}_{0}=29,30,31,32,33^{\circ} \mathrm{C}$ at fixed $\delta \mathrm{T}_{\mathrm{W}}=1{ }^{\circ} \mathrm{C}$; black: $\delta \mathrm{T}_{\mathrm{W}}=0.92,1.1,1.3,1.5,1.8^{\circ} \mathrm{C}$ at fixed $\mathrm{T}_{0}=29.5^{\circ} \mathrm{C}$; yellow: $\left(\mathrm{T}_{0}, \delta \mathrm{T}_{\mathrm{W}}\right)=(30,1.3){ }^{\circ} \mathrm{C}$. The white dashed box shows the $3 \leq \mathrm{U}_{\mathrm{h}} \leq 7 \mathrm{~m} / \mathrm{s}$ and $60 \leq \mathrm{h}_{1} \leq 120 \mathrm{~m}$ region where RI events are frequently observed. The model uses $\gamma=0.02$ and $\mathrm{V}_{0}=30 \mathrm{~m} / \mathrm{s}$. Add $3{ }^{\circ} \mathrm{C}$ to $\mathrm{T}_{0}$ to apply the plot to the Atlantic hurricanes, i.e., $29.5^{\circ} \mathrm{C}$ becomes $32.5^{\circ} \mathrm{C}, 30^{\circ} \mathrm{C}$ becomes $33^{\circ} \mathrm{C}$, etc.

\subsection{Observed RIs in the Present Climate}

Figure 5 plots the $\left(\delta \mathrm{T}_{\mathrm{W}}, \mathrm{T}_{0}\right)$ points of nine TCs whose RIs may be related to WOFs (source references in the caption). We only include Tropical Cyclone Bansi for comparison since the empirical MPI used is not for the South Indian Ocean. The magenta line shows the $15.4 \mathrm{~m} / \mathrm{s}$ using Xu et al.'s [35] empirical MPI coefficients for the North Atlantic. We use it to assess the four Atlantic hurricanes (E, $\mathrm{H}, \mathrm{Mw}$, and $\mathrm{O}$ ). The magenta line shifts slightly rightward and upward relative to the western North Pacific line (white) because the Atlantic's slope $\partial \mathrm{V}_{\mathrm{m}} / \partial \mathrm{T}$ is less steep (roughly $0.8: 1$ ). The 9-TCs' mean $\left(\delta \mathrm{T}_{\mathrm{W}}, \mathrm{T}_{0}\right)$ are $(0.87,28.8){ }^{\circ} \mathrm{C}$ (red asterisk), and the mean $\mathrm{U}_{\mathrm{h}}$ is $5.2 \mathrm{~m} / \mathrm{s}$. The plot shows that none of the TCs' rapid intensifications was WOF-induced. Typhoon Soudelor is the only storm that crosses the white $15.4 \mathrm{~m} / \mathrm{s}$-line. However, ocean cooling at $\mathrm{U}_{\mathrm{h}}=5.5 \mathrm{~m} / \mathrm{s}$ would also render a WOF-induced RI unlikely in Soudelor. Instead, Oey and Lin [16] argued that weakened environmental vertical wind shear $<4 \mathrm{~m} / \mathrm{s}$ contributes to the storm's RI [5]. They also suggested that weak vertical wind shears may have contributed to the RIs in Hurricane Opal [57] and Typhoon Maemi [16]. These results show that for WOF-induced RIs to develop, the WOF and ambient SST would have to be warmer than the present-day $\mathrm{T}_{0} \approx 28-29.5^{\circ} \mathrm{C}$ and $\delta \mathrm{T}_{\mathrm{W}} \lesssim 1{ }^{\circ} \mathrm{C}$. Thus, as stated before, RIs triggered by the WOF alone are unlikely to be frequent occurrences in the present climate. Oey and Huang [30] arrived at this same conclusion in numerical experiments designed to isolate the WOF-induced intensity change. They found that although WOF increases intensity, the intensification is insufficient to trigger more RIs. Consequently, the number of RIs is not statistically 
significantly different between ensemble simulations with and without the WOF included in the model.

\section{Discussion}

Three of the four listed typhoons in Figure 5 are close to the white $15.4 \mathrm{~m} / \mathrm{s}$-line. Thus, they are close to a "tipping point or line", meaning that slight increases in $\mathrm{T}_{0}$ or $\delta \mathrm{T}_{\mathrm{W}}$ or both may potentially foster more RIs. We use the simple model to project how WOF-induced RIs may evolve as the Earth's climate warms. The SST trend is $+0.1{ }^{\circ} \mathrm{C}$ per decade in the western North Pacific, but two times higher in the Philippines Sea (latitudes $\lesssim 20^{\circ} \mathrm{N}$ ) [58-60]. Similar warming trends occur in the Atlantic. At these rates and assuming that SST continues to rise [61], $\mathrm{T}_{0}$ would reach $30-31^{\circ} \mathrm{C}$ near the end of the 21st century.

SSTs in coastal seas and western boundary currents show higher rates of warming trends [60,62]. Along the western North Pacific rim and US southern and eastern shelves, coastal SST trends reach $+0.4{ }^{\circ} \mathrm{C}$ per decade in summer [62], approximately two times higher than the adjacent open seas. The value is consistent with a recent estimate of $\mid \nabla$ SST $\mid$ trends of more than $+0.2^{\circ} \mathrm{C} / 100 \mathrm{~km} /$ decade) across China's and Japan's coastal shelves, the northern Gulf of Mexico, the US south-mid-Atlantic, as well as across the Kuroshio and the Gulf Stream [60]. At these rates, the corresponding $\left.\delta \mathrm{T}_{\mathrm{W}}\right|_{\text {Coast }}$ and $\delta \mathrm{T}_{\mathrm{W}}{ }{ }_{\mathrm{WBC}}$ would reach $1.2-1.8{ }^{\circ} \mathrm{C}$ or more near the end of the 21 st century. The trend of $\left.\delta \mathrm{T}_{\mathrm{W}}\right|_{\mathrm{Eddy}}$ for mesoscale eddies is harder to estimate. In the western North Pacific, Martínez-Moreno et al. [60] show an increasing $|\nabla S S T|$ trend of $+0.02{ }^{\circ} \mathrm{C} /(100 \mathrm{~km} /$ decade $)$ for eddies north of $20^{\circ} \mathrm{N}$, but a decreasing trend of $-0.04{ }^{\circ} \mathrm{C} /(100 \mathrm{~km} /$ decade $)$ south of $20^{\circ} \mathrm{N}$. The trends in tropical and subtropical North Atlantic are similarly weakly decreasing. However, these values for $\left.\delta \mathrm{T}_{\mathrm{W}}\right|_{\text {Eddy }}$ are weaker with larger uncertainty than the trends of $\left.\delta \mathrm{T}_{\mathrm{W}}\right|_{\text {Coast }}$ or $\left.\delta \mathrm{T}_{\mathrm{W}}\right|_{\mathrm{WBC}}$.

Figure 6 (color shading) shows $\delta V_{m}$ as a function of $U_{h}$ and $h_{1}$ for $T_{0}=29.5^{\circ} \mathrm{C}$ and $\delta \mathrm{T}_{\mathrm{W}}=1{ }^{\circ} \mathrm{C}$ near their upper limits in the western North Pacific in the present climate. The white line shows the corresponding $\delta V_{m}=15.4 \mathrm{~m} / \mathrm{s}$ separating the $\left(\mathrm{U}_{\mathrm{h}}, \mathrm{h}_{1}\right)$ space on the upper right where a WOF-induced RI is possible from the lower-left where RI is unlikely. Ocean cooling is inversely related to $h_{1}$ or $U_{h}$ (Equations (15) and (16)). There is more (less) cooling as the upper layer gets thinner (thicker), or the storm translates slower (faster), or both. As a result, the atmospheric response is a weaker (stronger) $\delta \mathrm{V}_{\mathrm{m}}$ (Equation (3)). The white dashed box encloses the RI region's $Z_{26}$ range $(60-120 \mathrm{~m}$; Figure 3$)$ and the $\mathrm{U}_{\mathrm{h}}$ range (3-7 m/s; [36]), where the majority of RI events occur. Thus, as discussed before, one sees that WOF-induced RIs in the present climate $\mathrm{T}_{0} \lesssim 29.5^{\circ} \mathrm{C}$ and $\delta \mathrm{T}_{\mathrm{W}}=1{ }^{\circ} \mathrm{C}$ are unlikely.

Blue dashed lines show the sensitivity of intensity change to ambient SST at a fixed $\delta \mathrm{T}_{\mathrm{W}}=1^{\circ} \mathrm{C}$. These $15.4 \mathrm{~m} / \mathrm{s}$ lines shift left and down as the $\mathrm{T}_{0}$ increases, sweeping across the white dashed box. For example, for a future $\mathrm{T}_{0}=30^{\circ} \mathrm{C}$, WOF-induced RIs can occur over the small northeast corner of the box $U_{h}>5.5 \mathrm{~m} / \mathrm{s}$ and $Z_{26}>95 \mathrm{~m}$. When $T_{0}=31(32){ }^{\circ} \mathrm{C}$, the likelihood for WOF-induced RIs substantially increases as the region where $\delta \mathrm{V}_{\mathrm{m}}>15.4$ $\mathrm{m} / \mathrm{s}$ now occupies $60 \%$ (95\%) of the box.

Black lines show the sensitivity of intensity change to WOF's anomaly at a fixed $\mathrm{T}_{0}=29.5^{\circ} \mathrm{C}$. Note that the dependency of $\delta \mathrm{V}_{\mathrm{m}}$ on $\mathrm{h}_{1}$ or $\mathrm{U}_{\mathrm{h}}$ is unchanged, and one can always find $\mathrm{T}_{0}$ and $\delta \mathrm{T}_{\mathrm{W}}$ pair for which the blue dashed and black lines coincide. However, from Equation (20), $\left(\frac{\partial \delta \mathrm{V}_{\mathrm{m}}}{\partial \delta \mathrm{T}_{\mathrm{W}}}\right) /\left(\frac{\partial \delta \mathrm{V}_{\mathrm{m}}}{\partial \mathrm{T}_{0}}\right) \approx 1 /\left(\delta \mathrm{T}_{\mathrm{W}} \mathrm{C}\right)+0\left(\mathrm{~s} \mathrm{~F}_{\mathrm{T}}\right)$, where $\mathrm{C} \approx 0.18{ }^{\circ} \mathrm{C}^{-1}$ (see Section 2.2). Thus, $\delta V_{m}$ is $\sim 5$ times more sensitive to $\delta \mathrm{T}_{\mathrm{W}}$ than $\mathrm{T}_{0}$ (the sensitivity difference

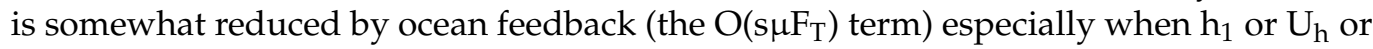
both are small). Thus a $1^{\circ} \mathrm{C}$ change in $\mathrm{T}_{0}$ takes only $\sim 0.2{ }^{\circ} \mathrm{C}$ change in $\delta \mathrm{T}_{\mathrm{W}}$ to effect the same intensity change. For example, Figure 6 shows that a $0.3^{\circ} \mathrm{C}\left(0.5^{\circ} \mathrm{C}\right)$ change of $\delta \mathrm{T}_{\mathrm{W}}$ from 1 to $1.3^{\circ} \mathrm{C}\left(1.5^{\circ} \mathrm{C}\right)$ increases the likelihood for WOF-induced RIs as the region where $\delta \mathrm{V}_{\mathrm{m}}>15.4 \mathrm{~m} / \mathrm{s}$ sweeps across more than $60 \%(95 \%)$ of the box. The effect is the same as a $1.5^{\circ} \mathrm{C}\left(2.5^{\circ} \mathrm{C}\right)$ change in $\mathrm{T}_{0}$ from 29.5 to $31(32){ }^{\circ} \mathrm{C}$. 
One may question the suitability of using the empirical MPI relationship (Equation (2)) based on present climate's data to make future inferences. In the absence of data, it is, of course, impossible to address this with absolute certainty. However, we can make some reasonable deductions that the empirical relation will remain valid, at least into the 21st century. First, the theoretical MPI critically depends on the saturation mixing ratio, which varies exponentially with SST according to the Clausius-Clapeyron relationship [63,64]. Thus, the exponential form of the empirical MPI relationship is likely to remain valid in the future. Second, any numerical change in the empirical MPI is likely to be 'slow'. Evidence of the slow change is that the exponent coefficient $C$ remains stable despite the different periods and regions in the four cited studies. In the North Atlantic, $\mathrm{C}=0.1813,0.1813$, and 0.1903 for the data from 1962-1992, 1981-2003, and 1988-2014, respectively [33-35], while $C=0.1806$ for the 1981-2003 data for the western North Pacific [6]. Zeng et al. [34] made a similar argument when noting that the $C$ they obtained was identical to DeMaria and Kaplan's [33] using an earlier dataset. Finally, in the simple model, the most critical parameter is the slope $\mathrm{s}$ on the T-space. Based on the three analysis periods for the North Atlantic hurricanes [33-35], s appears to be increasing. The $\mathrm{s}=10.12,11.71$, and $14.09 \mathrm{~m} / \mathrm{s}^{\circ} \mathrm{C}^{-1}$ for the 1962-1992, 1981-2003, and 1988-2014 data. We do not know the statistical significance of this increase. However, as long as this parameter is non-decreasing with time, the model would not overpredict WOF-induced RIs.

Rapid intensifications may become more frequent and storms more powerful as the planet warms [65]. Our simple model also predicts this as the likelihood for RI increases with increased ambient SST. Moreover, the greater sensitivity of RI to WOF anomaly suggests more powerful landfalling TCs as storms cross warmer coastal seas and western boundary currents. The simple model indicates that Western North Pacific coastlines: China and Japan, are particularly vulnerable. Wada [12] already suggests such a possibility with Typhoon Manyi crossing the warm Kuroshio south of Japan.

\section{Conclusions}

This study presents a simple analytical model with ocean feedback of tropical cyclones' rapid intensity change induced by warm ocean features (WOF). The model indicates that WOF-induced rapid intensification (RI) is unlikely in the present climate. We provide evidence of this inference using observations from nine TCs that developed RIs. We show that the observed RIs have parameters below the model's RI threshold. In other words, in the present climate, other environmental and internal dynamical factors likely contributed to the RIs observed in these TCs. The inference is in excellent agreement with the conclusion of a recent numerical study [30].

On the other hand, the simple model shows that WOF-induced RI is very sensitive to the WOF's anomalous amplitude, five times more sensitive than the background SST. Thus, as coastal seas and western boundary currents continue to warm in the 21st century, the model suggests an increased likelihood for RIs near the coasts, China and Japan in particular. Future work may seek to show evidence of this prediction by analyzing landfalling TCs. This model prediction that WOF-induced RI by increased $\left.\delta \mathrm{T}_{\mathrm{W}}\right|_{\text {Coast }}$ or $\delta \mathrm{T}_{\mathrm{W}} \mid \mathrm{WBC}$

Funding: This research received no external funding.

Institutional Review Board Statement: Not applicable.

Informed Consent Statement: Not applicable.

Data Availability Statement: The observational data presented in this study are available from the cited public links and references, IBTrACS (https://www.ncdc.noaa.gov/ibtracs/ accessed on 1 October 2021), and GHRSST (https:/ / www.ghrsst.org/ accessed on 1 October 2021).

Acknowledgments: I thank the three reviewers for their inputs. 
Conflicts of Interest: The author declares no conflict of interest. The funders had no role in the design of the study; in the collection, analyses, or interpretation of data; in the writing of the manuscript, or in the decision to publish the results.

\section{Appendix A. Symbols and Abbreviations}

\begin{tabular}{|c|c|}
\hline A, B, C & Coefficients of the empirical MPI \\
\hline c & Ocean's mode- 1 baroclinic phase speed \\
\hline $\mathrm{C}_{\mathrm{d}}$ & Drag coefficient \\
\hline $\mathrm{F}_{\mathrm{T}}$ & $\begin{array}{l}\text { Factor expressing the effect of TC-induced SST cooling (Equation (16)); the term } \\
\text { "s } \mathrm{sF}_{\mathrm{T}} \text { " couples TC's } \delta \mathrm{V}_{\mathrm{m}} \text { to ocean cooling }\end{array}$ \\
\hline $\mathrm{g}$ & Earth's gravity \\
\hline $\mathrm{h}_{1} \& \mathrm{~h}_{2}$ & Depths of the ocean's upper and lower layers, i.e. before mixing \\
\hline $\mathrm{L}$ & $\mathrm{TC}$ 's radius \\
\hline $\mathrm{P}$ & $=\mathrm{L} / \mathrm{U}_{\mathrm{h}}$, time taken for the $\mathrm{TC}$ to traverse its radius (i.e. half its size) \\
\hline PE & Raised potential energy, PE after mixing minus before mixing \\
\hline$\left.P E\right|_{\text {2layers }}$ & Ocean 2-layer system's potential energy before mixing \\
\hline$P E I_{\operatorname{mix}}$ & Ocean 1-layer system's potential energy after mixing \\
\hline $\mathrm{s}$ & slope of $V_{m}$ on the T-space: $\left.\left(\partial V_{m} / \partial T\right)\right|_{0}$ \\
\hline $\mathrm{t}$ & a general variable for time \\
\hline $\mathrm{T}$ & a general variable for SST \\
\hline $\mathrm{T}_{1}$ and $\mathrm{T}_{2}$ & Uniform temperatures of the ocean's upper and lower layers before mixing \\
\hline $\mathrm{T}_{\text {mix }}$ & Uniform temperature after mixing \\
\hline $\mathrm{T}_{0}$ & Ambient (i.e. background) SST (Figure 1) \\
\hline $\mathrm{U}_{\mathrm{h}}$ & TC translation speed \\
\hline $\mathrm{V}$ & $=|\mathbf{V}|$ wind speed of the wind vector $\mathbf{V}$ \\
\hline$V_{m}$ & MPI maximum wind \\
\hline $\mathrm{V}_{0}$ & Maximum wind of the TC approaching the WOF \\
\hline WE & Wind energy \\
\hline$x \& z$ & Horizontal and vertical axes, $\mathrm{z}=0$ at the sea surface \\
\hline$Z_{26} \& Z_{20}$ & Depths of the ocean's $26^{\circ} \mathrm{C}$ and $20^{\circ} \mathrm{C}$ isotherms \\
\hline$\alpha$ & thermal expansion coefficient of seawater $\approx 3 \times 10^{-4} \mathrm{~K}^{-1}$ at SST $\approx 28^{\circ} \mathrm{C}$ \\
\hline$\varrho_{\mathrm{a}}$ & Air density \\
\hline$\varrho_{0}$ & Reference seawater density $\approx 1025 \mathrm{~kg} / \mathrm{m}^{3}$ \\
\hline$\varrho_{1}$ and $\varrho_{2}$ & Uniform densities of ocean's upper and lower layers before mixing \\
\hline$\varrho_{\text {mix }}$ & Uniform seawater density after mixing \\
\hline$\delta \mathrm{T}$ & $\begin{array}{l}=\mathrm{T}_{\text {mix }}-\mathrm{T}_{1}(<0) \text {, the SST cooling due to TC (Equation (13)); used also as the } \\
\text { usual mathematical notation of "Change in } \mathrm{T}^{\prime} \text { (e.g. Equation (3)) }\end{array}$ \\
\hline$\delta \mathrm{T}_{0}$ & $<0$, ocean cooling caused by increased $\delta \mathrm{V}_{0}$ as the TC crosses into the WOF \\
\hline$\delta \mathrm{T}_{\mathrm{W}}$ & The WOF's SST anomaly $(>0)$; i.e. total WOF's SST $=\mathrm{T}_{0}+\delta \mathrm{T}_{\mathrm{W}}$ (Figure 1$)$ \\
\hline$\Delta \mathrm{T}$ & $=\mathrm{T}_{1}-\mathrm{T}_{2}(>0)$, the temperature difference between upper and lower layers \\
\hline$\Delta \varrho$ & $=\varrho_{1}-\varrho_{2}(<0)$, the density difference between upper and lower layers \\
\hline$\delta \mathrm{V}_{\mathrm{m}}$ & Change in MPI maximum wind (m/s) due to change in SST, see Equation (2) \\
\hline$\delta \mathrm{V}_{0}$ & Change in TC's maximum wind as it crosses over the WOF \\
\hline$\gamma$ & Mixing efficiency ( $\sim$ fraction of the wind work that goes into mixing) \\
\hline$\mu$ & Ratio of TC wind to MPI wind $=\mathrm{V}_{0} / \mathrm{V}_{\mathrm{m}} \leq 1$ \\
\hline$\mu_{1}, \mu_{2}, \mu_{3}$ & Coefficient variables used in the model solution (19) \\
\hline MPI & Maximum Potential Intensity \\
\hline POM & Princeton Ocean Model \\
\hline RI & Rapid Intensification \\
\hline SST & Sea Surface Temperature \\
\hline $\mathrm{TC}$ & Tropical Cyclone \\
\hline TS & Tropical Storm \\
\hline WOF & Warm Ocean Feature \\
\hline
\end{tabular}

\section{References}

1. Kaplan, J.; DeMaria, M. Large-scale characteristics of rapidly intensifying tropical cyclones in the North Atlantic basin. Weather Forecast. 2003, 18, 1093-1108. [CrossRef] 
2. Montgomery, M.T.; Nguyen, S.V.; Smith, R.K.; Persing, J. Do tropical cyclones intensify by WISHE? Q. J. R. Meteorol. Soc. 2009, 135, 1697-1714. [CrossRef]

3. Doyle, J.D.; Moskaitis, J.R.; Feldmeier, J.W.; Ferek, R.J.; Beaubien, M.; Bell, M.M.; Cecil, D.L.; Creasey, R.L.; Duran, P.; Elsberry, R.L.; et al. A view of tropical cyclones from above. BAMS 2017, 2113-2134. [CrossRef]

4. Chen, X.; Zhang, J.A.; Marks, F.D. A thermodynamic pathway leading to rapid intensification of tropical cyclones in shear. Geophys. Res. Lett. 2019, 46, 9241-9251. [CrossRef]

5. Paterson, L.A.; Hanstrum, B.N.; Davidson, N.E.; Weber, H.C. Influence of Environmental Vertical Wind Shear on the Intensity of Hurricane-Strength Tropical Cyclones in the Australian Region. Mon. Weather Rev. 2005, 133, 3644-3660. [CrossRef]

6. Zeng, Z.; Wang, Y.; Wu, C.C. Environmental dynamical control of tropical cyclone intensity-An observational study. Mon. Wea. Rev. 2007, 135, 38-59. [CrossRef]

7. Kaplan, J.; DeMaria, M.; Knaff, J.A. A revised tropical cyclone rapid intensification index for the Atlantic and eastern North Pacific basins. Weather Forecast. 2010, 25, 220-241. [CrossRef]

8. Hendricks, E.A.; Peng, M.S.; Fu, B.; Li, T. Quantifying environmental control on tropical cyclone intensity change. Mon. Weather Rev. 2010, 138, 3243-3271. [CrossRef]

9. Wu, L.; Su, H.; Fovell, R.G.; Wang, B.; Shen, J.T.; Kahn, B.H.; Hristova-Veleva, S.M.; Lambrigtsen, B.H.; Fetzer, E.J.; Jiang, J.H. Relationship of environmental relative humidity with North Atlantic tropical cyclone intensity and intensification rate. Geophys. Res. Lett. 2012, 39, L20809. [CrossRef]

10. Soloviev, A.V.; Lukas, R.; Donelan, M.A.; Haus, B.K.; Ginis, I. The air-sea interface and surface stress under tropical cyclones. Sci. Rep. 2014, 4, 5306. [CrossRef]

11. Soloviev, A.V.; Lukas, R.; Donelan, M.A.; Haus, B.K.; Ginis, I. Is the state of the air-sea interface a factor in rapid intensification and rapid decline of tropical cyclones? J. Geophys. Res. Oceans. 2017, 122, 10-174. [CrossRef]

12. Wada, A. Unusually rapid intensification of Typhoon Man-yi in 2013 under preexisting warm-water conditions near the Kuroshio front south of Japan. J. Oceanogr. 2015, 71, 131-156. [CrossRef]

13. Donelan, M.A. On the decrease of the oceanic drag coefficient in high winds. J. Geophys. Res. Oceans 2017, $123,1485-1501$. [CrossRef]

14. Chen, X.; Wang, Y.; Zhao, K. Synoptic flow patterns and large-scale characteristics associated with rapidly intensifying tropical cyclones in the South China Sea. Mon. Weather Rev. 2015, 143, 64-87. [CrossRef]

15. Zhang, L.; Oey, L. Young ocean waves favor the rapid intensification of tropical cyclones-a global observational analysis. Mon. Weather Rev. 2019, 147, 311-328. [CrossRef]

16. Oey, L.; Lin, Y. The Influence of Environments on the Intensity Change of Typhoon Soudelor. Atmosphere 2021, 12, 162. [CrossRef]

17. Kossin, J.P.; Olander, T.L.; Knapp, K.R. Trend analysis with a new global record of tropical cyclone intensity. J. Clim. 2013, 26, 9960-9976. [CrossRef]

18. Lee, C.-Y.; Tippett, M.K.; Sobel, A.H.; Camargo, S.J. Rapid intensification and the bimodal distribution of tropical cyclone intensity. Nat. Commun. 2016, 7, 10625. [CrossRef] [PubMed]

19. Emanuel, K.A. Thermodynamic control of hurricane intensity. Nature 1999, 401, 665-669. [CrossRef]

20. Schade, L.R.; Emanuel, K.A. The ocean's effect on the intensity of tropical cyclones: Results from a simple coupled atmosphereocean model. J. Atmos. Sci. 1999, 56, 642-651. [CrossRef]

21. Emanuel, K.; DesAutels, C.; Holloway, C.; Korty, R. Environmental control of tropical cyclone intensity. J. Atmos. Sci. 2004, 61, 843-858. [CrossRef]

22. Shay, L.K.; Goni, G.J.; Black, P.G. Effects of a warm oceanic feature on Hurricane Opal. Mon. Weather Rev. 2000, 128, 1366-1383. [CrossRef]

23. Hong, X.; Chang, S.W.; Raman, S.; Shay, L.K.; Hodur, R. The interaction between Hurricane Opal (1995) and a warm core ring in the Gulf of Mexico. Mon. Wea. Rev. 2000, 128, 1347-1365. [CrossRef]

24. Lin, I.I.; Wu, C.C.; Emanuel, K.; Lee, I.H.; Wu, C.R.; Pun, I.F. The interaction of Supertyphoon Maemi (2003) with a warm ocean eddy. Mon. Weather Rev. 2005, 133, 2635-2649. [CrossRef]

25. Ali, M.M.; Jagadeesh, P.V.; Jain, S. Effects of eddies on Bay of Bengal cyclone intensity. Eos Trans. Am. Geophys. Union 2007, 88, 93-95. [CrossRef]

26. Mainelli, M.; DeMaria, M.; Shay, L.K.; Goni, G. Application of oceanic heat content estimation to operational forecasting of recent Atlantic category 5 hurricanes. Weather Forecast. 2008, 23, 3-16. [CrossRef]

27. Jaimes, B.; Shay, L.K.; Uhlhorn, E.W. Enthalpy and momentum fluxes during Hurricane Earl relative to underlying ocean features. Mon. Weather Rev. 2015, 143, 111-131. [CrossRef]

28. Mawren, D.; Reason, C.J.C. Variability of upper-ocean characteristics and tropical cyclones in the South West Indian Ocean. J. Geophys. Res. Oceans 2017, 122, 2012-2028. [CrossRef]

29. Potter, H.; DiMarco, S.F.; Knap, A.H. Tropical Cyclone Heat Potential and the Rapid Intensification of Hurricane Harvey in the Texas Bight. J. Geophys. Res. Oceans. 2019, 124, 2440-2451. [CrossRef]

30. Oey, L.; Huang, S.M. Can a warm ocean feature caus a typhoon to intensify rapidly? Atmosphere 2021, 12, 797. [CrossRef]

31. Riehl, H. Some relations between wind and thermal structure of steady state hurricanes. J. Atmos. Sci. 1963, 20, 276-287. [CrossRef]

32. Gray, W.M. Global view of the origin of tropical disturbances and storms. Mon. Wea. Rev. 1968, 96, 669-700. [CrossRef] 
33. DeMaria, M.; Kaplan, J. Sea surface temperature and the maximum intensity of Atlantic tropical cyclones. J. Clim. 1994, 7, 1325-1334. [CrossRef]

34. Zeng, Z.; Chen, L.; Wang, Y. An observational study of environmental dynamical control of tropical cyclone intensity in the Atlantic. Mon. Weather Rev. 2008, 136, 3307-3322. [CrossRef]

35. Xu, J.; Wang, Y.; Tan, Z. The relationship between sea surface temperature and maximum intensification rate of tropical cyclones in the North Atlantic. J. Atmos. Sci. 2016, 73, 4979-4988. [CrossRef]

36. Zhang, L.; Oey, L. An observational analysis of ocean surface waves in tropical cyclones in the western North Pacific Ocean. J. Geophys. Res. Oceans 2019, 124, 184-195. [CrossRef]

37. Oey, L.Y.; Ezer, T.; Wang, D.P.; Fan, S.J.; Yin, X.Q. Loop current warming by Hurricane Wilma. Geophys. Res. Lett. 2006, 33, L08613 [CrossRef]

38. Oey, L.Y.; Ezer, T.; Wang, D.P.; Yin, X.Q.; Fan, S.J. Hurricane-induced motions and interaction with ocean currents. Cont. Shelf Res. 2007, 27, 1249-1263. [CrossRef]

39. Price, J.F. Upper Ocean Response to a Hurricane. J. Phys. Oceanogr. 1981, 11, 153-175. [CrossRef]

40. Chelton, D.B.; de Szoeke, R.A.; Schlax, M.G.; El Naggar, K.; Siwertz, N. Geographical variability of the first-baroclinic Rossby radius of deformation. J. Phys. Oceanogr. 1998, 28, 433-460. [CrossRef]

41. Xu, F.H.; Oey, L.Y. Seasonal SSH variability of the Northern South China Sea. J. Phys. Oceanogr. 2015, 45, 1595-1609. [CrossRef]

42. Gill, A.E. Atmosphere-Ocean Dynamics; Academic Press: Cambridge, MA, USA, 1982; p. 662.

43. Holland, G.J.; Belanger, J.I.; Fritz, A. A revised model for radial profiles of hurricane winds. Mon. Weather Rev. 2010, 138, 4393-4401. [CrossRef]

44. Chiang, T.L.; Wu, C.R.; Oey, L.Y. Typhoon Kai-Tak: A perfect ocean's storm. J. Phys. Oceanogr. 2011, 41, 221-233. [CrossRef]

45. Kunze, E. Near-inertial wave propagation in geostrophic shear. J. Phys. Oceanogr. 1985, 15, 544-565. [CrossRef]

46. Oey, L.Y.; Inoue, M.; Lai, R.; Lin, X.H.; Welsh, S.E.; Rouse, L.J., Jr. Stalling of near-inertial waves in a cyclone. Geophys. Res. Lett. 2008, 35, L12604. [CrossRef]

47. Powell, M.D.; Vickery, P.J.; Reinhold, T.A. Reduced drag coefficient for high wind speeds in tropical cyclones. Nature 2003, 422, 279-283. [CrossRef] [PubMed]

48. Good, S.A.; Martin, M.J.; Rayner, N.A. EN4: Quality controlled ocean temperature and salinity profiles and monthly objective analyses with uncertainty estimates. J. Geophys. Res. Oceans 2013, 118, 6704-6716. [CrossRef]

49. Sun, J.; Oey, L.Y. The influence of ocean on Typhoon Nuri (2008). Mon. Weather Rev. 2015, 143, 4493-4513. [CrossRef]

50. Sun, J.; Oey, L.Y.; Chang, R.; Xu, F.; Huang, S.M. Ocean response to typhoon Nuri (2008) in western Pacific and South China Sea. Ocean. Dyn. 2015, 65, 735-749. [CrossRef]

51. Etemad-Shahidi, A.; Imberger, J. Anatomy of turbulence in a narrow and strongly stratified estuary. J. Geophys. Res. 2002, 107, 3070. [CrossRef]

52. Bouffard, D.; Boegman, L.A. Diapycnal diffusivity model for stratified environmental flows. Dyn. Atmos Oceans 2013, 61, 14-34. [CrossRef]

53. Monismith, S.G.; Koseff, J.R.; White, B.L. Mixing efficiency in the presence of stratification: When is it constant? Geophys. Res. Lett. 2018, 45, 5627-5634. [CrossRef]

54. Smyth, W.D. Marginal instability and the efficiency of ocean mixing. J. Phys. Oceanogr. 2020, 50, 2141-2150. [CrossRef]

55. Sayol, J.M. On the Complexity of Upper Ocean Mesoscale Dynamics. Ph.D Thesis, IMEDEA(CSIC-UIB), Majorca, Spain, 2016; p. 178.

56. Balaguru, K.; Foltz, G.R.; Leung, L.R.; Hagos, S.M.; Judi, D.R. On the use of ocean dynamic temperature for hurricane intensity forecasting. Weather Forecast. 2018, 33, 411-418. [CrossRef]

57. Bozart, L.E.; Velden, C.S.; Bracken, W.D.; Molinari, J.; Black, P.G. Environmental influences on the rapid intensification of Hurricane Opal (1995) over the Gulf of Mexico. Mon. Weather Rev. 2000, 128, 322-352. [CrossRef]

58. Oliver, E.C.J. Mean warming not variability drives marine heatwave trends. Clim. Dyn. 2019, 53, 1653-1659. [CrossRef]

59. Seager, R.; Cane, M.; Henderson, N.; Lee, D.E.; Abernathey, R.; Zhang, Z. Strengthening tropical Pacific zonal sea surface temperature gradient consistent with rising greenhouse gases. Nat. Clim. Chang. 2019, 9, 517-522. [CrossRef]

60. Martinez-Moreno, J.; Hogg, A.; England, M.H.; Constantinou, N.C.; Kiss, A.E.; Morrison, A.K. Global changes in oceanic mesoscale currents over the satellite altimetry record. Nat. Clim. Chang. 2021, 11, 397-403. [CrossRef]

61. Flato, G.; Marotzke, J.; Abiodun, B.; Braconnot, P.; Chou, S.C.; Collins, W.; Cox, P.; Driouech, F.; Emori, S.; Eyring, V.; et al. Evaluation of climate models. In IPCC Report Chapter 9; Cambridge University Press: Cambridge, UK; New York, NY, USA, 2013.

62. Lima, F.P.; Wethey, D.S. Three decades of high-resolution coastal sea surface temperatures reveal more than warming. Nat. Commun. 2012, 3, 704. [CrossRef] [PubMed]

63. Emanuel, K.A. The theory of hurricanes. Annu. Rev. Fluid Mech. 1991, 23, 179-196. [CrossRef]

64. Lighthill, J. Ocean spray and the thermodynamics of tropical cyclones. J. Engr. Math. 1999, 35, 11-42. [CrossRef]

65. Kossin, J.P.; Knapp, K.R.; Olander, T.L.; Velden, C.S. Global increase in major tropical cyclone exceedance probability over the past four decades. Proc. Natl. Acad. Sci. USA 2020, 117, 11975-11980. [CrossRef] [PubMed] 